\title{
HUMAN TRICHINELLOSIS IN HUNGARY fROM 1965 TO 20091
}

\author{
GLATZ K.*, DANKA J.*, KUCSERA I.* \& POZIO E.**
}

\section{Summary:}

Human trichinellosis was first documented in Hungary in 1891 and then there were an increased number of reports up to 1964 when the most severe outbreak occurred. After that, no information was available on the international literature on human trichinellosis which occurred from 1965 up to the present years. The aim of this study was to collect all the data available in Hungarian official datasources on human trichinellosis which occurred from 1965 up to 2009 in Hungary. Furthermore, a comparative analysis was performed on the different serological tests used along the 45 years of investigation. In the period in question, 573 infections were documented in Hungary. Of them, 57 occurred in the years 196569, 130 in 1970-79, 302 in 1980-89, 27 in 1990-99, and 57 in 2000-09. The most common sources of infection were pork from backyard pigs and hunted wild boars. Sporadic cases and small family outbreaks marked the last ten years. The comparison of serological tests shows that the ELISA is a good test for the first screening, but ELISA-positive serum samples should be confirmed by western blot except for clinically clear-cut cases.

KEY WORDS: trichinellosis, epidemiology, serology, backyard pig, wild boar, Hungary.

1 richinellosis is a zoonotic disease caused by the consumption of raw or semi-raw meat of many animals species (e.g., domestic and wild swine, horses, bears, walruses) infected with larvae of parasitic nematodes belonging to the genus Trichinella, which shows a cosmopolitan distribution (Gottstein et al., 2009). In the last 25 years in the European Union, trichinellosis has been documented in 14 member states, but for some countries the information has been not routinely reported and very few data are available in the literature (Pozio, 2007).

In Hungary, human trichinellosis was first documented in 1891 and up to 1950, 114 cases with nine deaths have

\footnotetext{
* Department of Parasitology, National Center for Epidemiology, Gyáli út 2-6, 1097 Budapest, Hungary.

** Department of Infectious Parasitic and Immunomediated Diseases, Istituto Superiore di Sanità, Rome, Italy

Correspondence: Itsvan Kucsera

Tel.: + 3614761233 - Fax: + $361476-1233$

E-mail: kucsera.istvan@oek.antsz.hu

${ }^{1}$ This article is based on an oral presentation given at the international conference "Parasitic zoonoses in present day Europe", Belgrade, 18-20 November 2009 .
}

Résumé : La trichinellose humaine en Hongrie, de 1965 à 2009

La trichinellose humaine en Hongrie a été documentée depuis 1891, avec une augmentation du nombre de cas jusqu'à 1964, date d'une très sévère épidémie. Depuis 1964 aucune information sur le sujet n'a été publiée. Le but de cette étude était de récolter toutes les données officielles sur les cas de trichinellose humaine en Hongrie entre 1965 et 2009. De plus, une analyse comparative a été conduite sur les différents tests sérologiques utilisés au cours de ces 45 ans d'investigation. Au total, 573 infections ont été documentées en Hongrie dans la période concernée : 57 cas entre 1965 et 1969, 130 entre 1970 et 1979, 302 entre 1980 et 1989, 27 entre 1990 et 1999, et 57 entre 2000 et 2009. La viande de porc d'élevage et celle des sangliers sont les sources les plus communes d'infection. Des cas sporadiques, ainsi que des petites épidémies familiales ont été observés ces dernières années. L'analyse comparative des tests sérologiques a montré la fiabilité du test ELISA pour un premier dépistage, mais les résultats positifs avec ce test doivent être confirmés par Western Blot, à l'exception des cas cliniquement évidents.

MOTS CLÉS : trichinellose, épidémiologie, sérologie, porc d'élevage, sanglier, Hongrie.

been recorded (Nemeséri, 1970). Afterwards in 1964, the most severe outbreak occurred in Hungary with 116 infected persons three of them died for the consumption of raw sausages made by pork from a highly infected (200 larvae/g) sow (Kim, 1983).

The aims of this study were to collect epidemiological information on human trichinellosis, which occurred in Hungary from 1965 to 2009 and to compare the results obtained by different serological tests used at the Department of Parasitology of the National Center for Epidemiology.

\section{MATERIALS AND METHODS}

\section{EPIDEMIOLOGICAL DATA-SOURCES}

o collect the information on the trichinellosis infections in humans, the following sources were used: (i) year-books, namely the 70 year anniversary, the annals (Function of the National Institute of Public Health from 1927 to 1997. Seventy years 
Anniversary, 1998; Yearbooks of the National Institute of Public Health 1975-1997; Yearbooks of the Johan Béla National Center for Epidemiology 1998-2005; Yearbooks of the National Center for Epidemiology 20062009), and yearly epidemiological reports published by the National Institute of Public Health from 1927 to 1998, by the Johan Béla National Center for Epidemiology from 1998 to 2005, and by the National Center for Epidemiology (NCE) from 2006 to 2009 (National Institute of Public Health, Budapest, 1959; National Institute of Public Health, Budapest, 1966-1993; Supplements of Epinfo, 2-17, 1995-2009); (ii) electronic databases that are operating since 2000: "MedBakter" (MB), used for the storage of laboratory data by the laboratory departments of the NCE and the Epidemiological Surveillance System (ESSIN), the Hungarian official national database used for the storage of clinical, epidemiological, and laboratory data of human infections recorded by the National Public Health and Medical Officers Service in Hungary to supply data for the Ministry of Health. Furthermore, information was collected from the Food and Feed Safety Directorate of Central Agricultural Office of Hungary (Búza \& Józwiak, 2008).

\section{SEROLOGICAL TESTS FOR HUMAN TRICHINELLOSIS}

In the last forty years, four serological tests have been used to detect anti Trichinella IgG in human sera at the Department of Parasitology, National Center for Epidemiology, Budapest, at different times. The microprecipitation (MP) test with living larvae of Trichinella spiralis has been performed according to Roth (1941), since the early 1970's. A home-made ELISA (h-ELISA) using excretory-secretory (ES) antigens of T. spiralis larvae, performed according to van Knapen et al. (1982), was used from 1998 to 2002. Reading was performed at $492 \mathrm{~nm}$ wavelength with an automatic photometer; the optimal dilution of ES antigens, the samples, and the conjugate were determined by check-board titration using sera of patients with laboratory confirmed trichinellosis (positive by MP), and negative control sera. The cut off value was set at 0.4-0.5 OD to get the best correlation between clinical and laboratory data.

A commercial ELISA kit (c-ELISA) (NovaTec Immunodiagnostica GmbH D-63128 Dietzenbach, Germany), and a commercial western blot (WB) test (LDBIO DIAGNOSTICS, 69009 Lyon, France) have been used since 2002, and 2004, respectively, following the manufacturer's instructions. Sera of patients with clinical signs and symptoms and laboratory confirmed trichinellosis (positive by MP), negative control sera (NCE), and positive and negative reference sera supplied by the manufacturer, were used as controls. The results of the c-ELISA have been interpreted following the manufacturer's instructions: positive $=\mathrm{OD}>$ cut-off $+10 \%$, negative $=$ OD $<$ cut-off $-10 \%$, grey-zone $=$ cut-off
$-10 \% \leqslant$ OD $\leqslant$ cut-off $+10 \%$. The WB results were also interpreted following the manufacturer's instructions: positive when there was the simultaneous presence of the well defined P43-44 and P64 kDa bands, negative when no band was recognized and questionable when there was a band of P43-44 kDa, but no band at P64 kDa.

\section{RESULTS}

EPIDEMIOLOGY FROM THE 1950's TO 2009

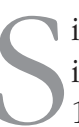
ince human trichinellosis had been the most important parasitic zoonosis in Hungary in the 1950's (Johan Béla National Center for Epidemiology, Budapest, 1998; Búza \& Józwiak, 2008), the official meat inspection was introduced in 1962 using the country-wide net of laboratories that had been built by the Meat Industrial Veterinary Control Service (HÁESZ) following a decree passed by the Cabinet in 1953 (Kozár, 1953), and a decision passed by the Economic Committee in 1959. Since 1958, trichinellosis has been subjected to duty, to give notice by the National Public Health and Medical Officers Service to the Ministry of Health (National Institute of Public Health, Budapest, 1959).

As forceful official control measures were introduced and have been adequately applied since the 1960's (Búza \& Józwiak, 2008), the yearly incidence of human trichinellosis decreased to less than 0.7 cases/ 100,000 inhabitants up to the 1980 's, and to less than 0.07 cases/100,000 inhabitants up to the 1990's (National Institute of Public Health, Budapest, 1966-1993; Supplements of Epinfo, 2-17, 1995-2009; Búza \& Józwiak, 2008). More detailed epidemiological data (geographical distribution of notified cases and outbreak description) are available since 1965 (National Institute of Public Health, Budapest, 1966-1993; Supplements of Epinfo, 2-17, 1995-2009). Comparing the morbidity decade by decade, we can find out that it was lower in the 1970's than in the 1960's, but it increased again in the 1980's. Trichinellosis cases of these decades which were officially not reported but which were highlighted in our study $(n=6)$ examining the yearbooks (National Institute of Public Health, Budapest, 1976-1998) do not alter the yearly incidence. Pork from backyard pigs and/or wild boars (Sus scrofa) was always the source of infection for the outbreaks notified from 1965 up to 1994. In the 1990's, there was only one outbreak in the year 1991.

The number of affected people of the notified outbreaks, the sources of infections, and the county or country of origin for imported infections are shown in Table I. In addition to trichinellosis outbreaks, sporadic cases have been also documented. Sixteen sporadic infections were 


\begin{tabular}{|c|c|c|c|c|c|}
\hline Years & $\begin{array}{l}\text { No. of infected } \\
\text { persons per } \\
\text { outbreak }\end{array}$ & $\begin{array}{c}\text { No. of single cases } \\
\text { in the period in } \\
\text { question }\end{array}$ & Source of infection & $\begin{array}{l}\text { Hungarian county } \\
\text { or country of origin }\end{array}$ & Reference \\
\hline \multirow[t]{5}{*}{$1965-69^{\mathrm{a}}$} & 12 & & backyard pig & Szabolcs & $\mathrm{b}$ \\
\hline & 8 & & backyard pig & Heves & b \\
\hline & 18 & & backyard pig and wild boar & Szabolcs & b \\
\hline & 3 & & wild boar & Fejér & b \\
\hline & - & $16^{\mathrm{a}}$ & unknown & several & $\mathrm{c}, \mathrm{b}$ \\
\hline \multirow{4}{*}{$1970-74$} & 8 & & backyard pig & Szabolcs & b \\
\hline & 7 & & backyard pig & Nógrád & $\mathrm{b}$ \\
\hline & 37 & & backyard pig & Szabolcs & b \\
\hline & 10 & & backyard pig & Szabolcs & b \\
\hline \multirow[t]{4}{*}{$1975-79$} & $48^{\mathrm{d}}$ & & backyard pig and wild boar & Borsod & b \\
\hline & 9 & & wild boar & Borsod & b \\
\hline & 2 & & unknown & unknown & b \\
\hline & - & 9 & unknown & several & $\mathrm{c}, \mathrm{b}$ \\
\hline \multirow[t]{4}{*}{ 1980-84 } & $50^{\mathrm{e}}$ & & backyard pig and wild boar & Pest & b \\
\hline & $20^{\mathrm{f}}$ & & backyard pig and wild boar & Borsod & $\mathrm{b}$ \\
\hline & $66^{\mathrm{g}}$ & & wild boar & Veszprém & b \\
\hline & 71 & & wild boar & Borsod & b \\
\hline \multirow[t]{5}{*}{$1985-89$} & 21 & & wild boar & Borsod & b \\
\hline & 13 & & wild boar & Komárom & b \\
\hline & 32 & & backyard pig and wild boar & Borsod & b \\
\hline & 21 & & wild boar & Pest & b \\
\hline & - & 8 & unknown & several & $\mathrm{c}, \mathrm{b}$ \\
\hline \multirow[t]{2}{*}{ 1990-99 } & 6 & & backyard pig & Pest & b \\
\hline & & 21 & unknown & several & $\mathrm{c}, \mathrm{b}, \mathrm{h}, \mathrm{i}$ \\
\hline \multirow[t]{7}{*}{ 2000-04 } & $2^{j}$ & & unknown & Békés & ESSIN $^{k}$ \\
\hline & $2^{1}$ & & suspected wild deer & Veszprém & ESSIN $^{k}$ \\
\hline & 3 & & imported sausages & Transylvania, Romania & ESSIN $^{k}$ \\
\hline & 2 & & imported sausages & Romania & ESSIN $^{\mathrm{k}}$ \\
\hline & $3^{\mathrm{m}}$ & & imported sausages & Romania & ESSIN $^{k}$ \\
\hline & 3 & & imported sausages & Transylvania, Romania & ESSIN $^{k}$ \\
\hline & $2^{\mathrm{n}}$ & & sausages & $\begin{array}{c}\text { unknown locality of } \\
\text { Hungary }\end{array}$ & ESSIN $^{k}$ \\
\hline \multirow[t]{6}{*}{ 2005-09 } & $2^{\circ}$ & & meat from black market & $\begin{array}{c}\text { unknown locality of } \\
\text { Hungary }\end{array}$ & $\mathrm{MB}^{\mathrm{P}}$ \\
\hline & $2^{\mathrm{q}}$ & & meat purchased at a family farm & Szabolcs & $\mathrm{MB}^{\mathrm{p}}$ \\
\hline & $1^{\mathrm{r}}$ & & unknown & unknown & $\mathrm{MB}^{\mathrm{p}}$ \\
\hline & $5^{s}$ & & Hungarian commercial ham & unknown & ESSIN $^{k}$ \\
\hline & $13^{\mathrm{t}}$ & & backyard pig & Békés & ESSIN $^{k}$ \\
\hline & - & 17 & unknown & several & $\mathrm{h}, \mathrm{i}, \mathrm{u}$ \\
\hline
\end{tabular}

${ }^{a}$ no data is available for $1968 ;{ }^{b}$ National Institute of Public Health, Budapest, 1966-1993; ${ }^{c}$ National Institute of Public Health, Budapest, 1976-1998; d of the 48 infected people, 29 were asymptomatic but showed a positive serology; ${ }^{\mathrm{e}}$ of the 50 infected people, four were asymptomatic but showed a positive serology; ${ }^{\mathrm{f}}$ of the 20 infected people, two were asymptomatic but showed a positive serology; ${ }^{\mathrm{g}}$ of the 66 infected people, 59 were asymptomatic but showed a positive serology; ${ }^{\mathrm{h}}$ Johan Béla National Center for Epidemiology, Budapest,

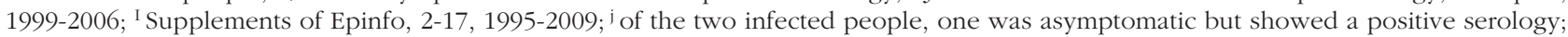
${ }^{\mathrm{k}}$ Epidemiological Surveillance System; ${ }^{1}$ of the three infected people, one was asymptomatic but showed a positive serology; ${ }^{\mathrm{m}}$ officially unreported infections; ${ }^{\mathrm{n}}$ officially unreported suspected infections; ${ }^{\circ}$ officially unreported suspected infections; " "MedBakter", an electronic database that is operating since 2000 ; ${ }^{\mathrm{q}}$ officially unreported infections, one of which was asymptomatic but showed a positive serology; ${ }^{\mathrm{r}}$ one confirmed but unreported clinical infection, the patient claimed that there was a cluster of trichinellosis cases in the Szabolcs county, but epidemiological data are missing; ${ }^{s}$ of the five infected people, two were asymptomatic but showed a positive serology and one was an officially unreported infection; ${ }^{\mathrm{t}}$ of the 13 infected people, five were asymptomatic but showed a positive serology; ${ }^{\mathrm{u}}$ National Center for Epidemiology, Budapest, 2007-2010.

Table I. - Epidemiological data on human trichinellosis which occurred in Hungary from 1965 to 2009. 
recorded between 1965 and 1969; nine (two of which imported) in the 1970's; eight (four of which imported) in the 1980's; 21 (two of which imported) in the 1990's; and 17 (seven of which imported) between 2000 and 2009 (National Institute of Public Health, Budapest, 1976-1998; Johan Béla National Center for Epidemiology, Budapest, 1999-2006; National Center for Epidemiology, Budapest, 2007-2010; National Institute of Public Health, Budapest, 1966-1993; Supplements of Epinfo, 2-17, 1995-2009). A trichinellosis infection was considered imported when the person who acquired the infection abroad became ill in Hungary. Most of sporadic infections were officially notified and occurred in Budapest, the Hungarian capital. A few sporadic infections were notified from further eight counties (the capital is an independent administrative unit in Hungary referred as a county in the Hungarian statistics).

In the last decade, 31 trichinellosis infections were officially reported in the yearly reports without laboratory information for five of them (Supplements of Epinfo, 2-17, 1995-2009), whereas some further infections were electronically notified (ESSIN), but not reported in the yearly reports. According to the MB data, 22 further people (one of whom was a foreign people) were not notified but trichinellosis had been serologically confirmed. Of the 57 infections documented in the last decade in our data-sources, 17 were sporadic, and 15 of them were not notified. Forty patients were involved in outbreaks, seven of them were not notified. Little is known about the infectious sources of sporadic cases of the same period. Clinical data confirming acute trichinellosis in five sporadic infections were recorded in the MB in 2000: two of them were not electronically notified and consequently they were officially not reported, none of them was abroad in the incubation period suggesting an Hungarian origin of the infections, three of these infections linked in time and space, claimed to have consumed raw meat before the appearance of clinical signs and symptoms. The presumed source of infection of further three sporadic cases which were detected in 2008 and 2009 , had a foreign origin, i.e. two Hungarian people ate sausages imported illegally from Romania (one patient ate a Romanian commercial product that had been produced in butcher's shop which had been closed because of a high number of trichinellosis infections caused by the consumption of their products; one patient ate a home-made sausage from game meat), and the third Hungarian people had lived in The Ukraine for many years and suffered from chronic muscle pain.

\section{SEROLOGICAL TESTS}

Between 1974 and 1979, serum samples from 656 persons were tested by MP (927 sera) (National Institute of Public Health, Budapest, 1976-1998). In the 1980's, serum samples from 1,979 persons were tested: 4,147 by MP and 677 by h-ELISA. In the 1990's, serum samples from 1,470 persons were tested: 1,397 by MP and 190 by h-ELISA (National Institute of Public Health, Budapest, 1976-1998; Johan Béla National Center for Epidemiology, Budapest, 1999-2006). The number of persons who tested positive, 64 in 1975-79; 214 in 1980-89; and 17 in 1990-99 (National Institute of Public Health, Budapest, 1976-1998; Johan Béla National Center for Epidemiology, Budapest, 1999-2006), was different from the number of notified infections in the same period of time which were 31, 233 and 23, respectively (National Institute of Public Health, Budapest, 1966-1993; Supplements of Epinfo, 2-17, 1995-2009), because not all the infected people were tested by serology, seroconversion was not documented in all clinically infected persons at the time of blood collection, some people were asymptomatic but they tested positive, and some officially not reported infections were only documented in the yearbooks (National Institute of Public Health, Budapest, 1976-1998; Johan Béla National Center for Epidemiology, Budapest, 1999-2006). From 1975 to 2000, six chronic infections of unknown origin and five acute, imported infections were officially unreported. In 1987, a serosurvey was organized to investigate the seroprevalence in the Borsod-Abaúj-Zemplén (BAZ) county, where the human trichinellosis was the most important parasitic disease at that time (see Table I) (National Institute of Public Health, Budapest, 1976-1998). Out of 398 serum samples from asymptomatic persons not linked to any outbreak, a serum $(0.25 \%)$ tested positive by both MP and h-ELISA.

From 2000 to 2009, 1,460 serum samples collected from 1,180 people with suspected trichinellosis were tested by MP $(\mathrm{N}=1,319)$, h-ELISA $(\mathrm{N}=535)$, c-ELISA $(\mathrm{N}=624)$, and WB $(\mathrm{N}=162)$. Eighty-two $(6.9 \%)$ people were positive by at least one ELISA; of them, 52 (63.4\%) tested positive also by MP or WB. Eleven people showed seroconversion. The WB analysis showed a remarkable sensitivity and specificity confirming its use as confirmatory test (Alcantra \& Correa, 1993; De La Rosa et al., 1995; Mahannop et al., 1995). Only in the $6.8 \%$ of WB tests, the result was questionable or not valuable. The frequency of grey-zone results was $4.3 \%$, and $9.9 \%$ by the h-ELISA, and the c-ELISA, respectively. The frequency of positive reactions was $3.2 \%, 3.5 \%$, and $11 \%$ by the MP, the h-ELISA, and the c-ELISA, respectively. Sera from 45 people were found to be reactive ( 25 positive, 20 questionable) by the c-ELISA but negative by WB and MP. Regarding this high number of questionable, and discrepant positive results, a small comparative analysis was performed on the laboratory results by the different techniques used in the last decade. Since ELISA-s are sensitive tests but less specific than WB assays, the detection of a high number of sera with an OD value considered to be questionable, strongly 
suggests that most of these sera were false positive. Literature data support this hypothesis, because worms of the genus Trichinella share a lot of antigens in common with other parasites (Gómez-Morales et al., 2008).

\section{DISCUSSION}

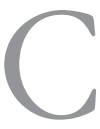
omparing the prevalence of trichinellosis of the South-Eastern European countries that undergone political-economical changes similar to those of Hungary in the last two decades, we found that a high incidence (hundreds of human cases per year) of infections was reported in Bulgaria, Croatia, Romania, and Serbia, a moderate incidence was found in Bosnia Herzegovina, while trichinellosis can be considered to be rare and sporadic in Greece, Macedonia and Montenegro (Cuperlovic et al., 2005).

In our study, all the official data on human trichinellosis, which occurred in Hungary in the last five decades, were collected. The highest morbidity of 1.2 cases per 100,000 inhabitants of 1964 dropped to 0.2 of the late 1970 's, and to 0.06 and 0.08, in the last two decades, respectively. In the 1980's, there was an increase up to 0.7 per 100,000 inhabitants, due to large outbreaks. For the last two decades, sporadic cases and small family outbreaks were found to be characteristic. The consumption of pork from hunted wild boars and from backyard pigs, and the consumption of improperly processed meat products from black-markets were the sources of the small outbreaks, most of which were linked to Romania. Wild deer meat was suspected to be the source of infection of an outbreak, which occurred in 2001, but it was not proved. According to the geographical origin of the human infections, which occurred in the last decade, they were documented in twelve counties which are those bordering Croatia, Romania, the Ukraine, and Serbia, and those where there were a high number of immigrants and flourishing black markets such as counties surrounding the Hungarian capital and the Lake Balaton. Since the meat inspection of back-yard pigs and of improperly processed meat products sold at the black-market is quite impossible, the control of these infections can be achieved only by social and economical changes and by the consumer education in Hungary.

Summarizing all the data from the last decade, we found that there are only a few notified confirmed infections without any laboratory result, but there are many people with serologically confirmed trichinellosis who never were notified and reported. Possible explanations could be: 1) a heavy lay-off of the Hungarian national publichealth system in 2004 that might have led to neglect human trichinellosis since the low morbidity; and 2) a long change period and the shift to the national electronic notification system ESSIN between 2000 and 2003. At the beginning of the 70's at the Department of Parasitology (NCE, Hungary), MP with living larvae of T. spiralis, was the most suitable serological method when the MP results are compared with those of the indirect haemagglutination and complement fixation reaction (National Institute of Public Health, Budapest, 1976-1998). At that time, the use of serology strongly supported the early clinical diagnosis, an early treatment of infected people and enabled to identify chronic infections, since circulating anti-Trichinella IgG are detectable many years after the infection (Fröscher et al., 1988).

\section{ACKNOWLEDGEMENTS}

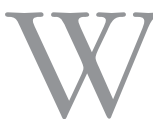

e thank Andrásné Szilágyi (Department of Epidemiology, National Center for Epidemiology, Budapest, Hungary) for her help in the collection of epidemiological data registered in the electronic database "ESSIN", Tusják Katalin, and Csák Györgyi for their excellent laboratory assistance.

\section{REFERENCES}

A Johan Béla Országos Epidemiológiai Központ múködése (1998-2005). Yearbooks of the Johan Béla National Center for Epidemiology 1998-2005. Published annually by the Johan Béla National Center for Epidemiology, Budapest, 1999-2006.

AlCantra P. \& Correa D. Human humoral immune responses against Trichinella spiralis. International Journal for Parasitology, 1993, 23, 657-660.

Az Országos Epidemiológiai Központ múködése (2006-2009). Yearbooks of the National Center for Epidemiology 20062009. Published annually by the National Center for Epidemiology, Budapest, 2007-2010.

Az Országos Közegészségügyi Intézet 70 éves múködése 19271997. Jubileumi évkönyv. Function of the National Institute of Public Health from 1927 to 1997. Seventy years Anniversary. Published by the Johan Béla National Center for Epidemiology, Budapest, 1998.

Az Országos Közegészségügyi Intézet múködése az 1958. évben. Yearbook of the National Institute of Public Health 1958. Published by the National Institute of Public Health, Budapest, 1959.

Az Országos Közegészségügyi Intézet múködése (1975-1997). Yearbooks of the National Institute of Public Health 19751997. Published annually by the National Institute of Public Health, Budapest, 1976-1998.

Búza L. \& Józwiak Á. Trichinellosis. Congress book of the Hungarian symposium on zoonotic infections, 2008, 149-161. 
Cuperlovic K., Djordjevic M. \& Pavlovic S. Re-emergence of trichinellosis in southeastern Europe due to political and economic changes. Veterinary Parasitology, 2005, 132, 159-166.

De-La-Rosa J.L., Alcantra P. \& Correa D. Investigation of cross-reactions against Trichinella spiralis antigens by Enzyme-Linked Immunosorbent Assay and Enzyme-Linked Immunoelectrotransfer Blot Assay in patients with various diseases. Clinical and Diagnostic Laboratory Immunology, 1995, 2, 122-124.

Éves jelentések Magyarország járványügyi helyzetéról, 19651992. Annual reports on the epidemiological situation in Hungary 1965-1992. Published annually by the Department of Epidemiology, National Institute of Public Health, Budapest, 1966-1993.

Éves jelentések Magyarország járványügyi helyzetéról, 19932009. Annual reports on the epidemiological situation in Hungary. Published annually by the National Center for Epidemiology, and its predecessors. Supplements of Epinfo, 2-17, 1995-2009.

FrÖscher W., Gullotta F., SAathoff M. \& TACKmann W. Chronic trichinosis. Clinical, bioptic, serological and electromyographic observations. European Neurology, 1988, 28, 221-226.

Gómez-Morales M.A., Ludovisi A., Amati M., Cherchi S., Pezzotti P. \& Pozio E. Validation of an enzyme-linked immunosorbent assay for diagnosis of human trichinellosis. Clinical and Vaccine Immunology, 2008, 15, 1723-1729.

GotTstein B., Pozio E. \& Nöckler K. Epidemiology, diagnosis, treatment, and control of trichinellosis. Clin. Microbiol. Rev., 2009, 22, 127-145.

KIM C.W: Geographic distribution and prevalence, in: Trichinella and trichinosis. Kampbell W.C. (Ed.), Plenum Press, New York and London, 1983, 445-500.

KOZÁr Gy. Organization and function of Meat Industrial Veterinary Control Service 1953. VIII. 1. - 1963. III. 31. http://konyvtar.univet.hu/haesz/haesz.pdf (in Hungarian language).

Mahannop P., Setasuban P., Morakota N., Tapchaisri P. \& CHAICUMPA W. Immunodiagnosis of human trichinellosis and identification of specific antigen for Trichinella spiralis. International Journal for Parasitology, 1995, 25, 87-94.

NemesérI L. The importance of trichinellosis in Hungary. Wiad. Parazytol., 1970, 16, 80-83.

PozIo E. World distribution of Trichinella spp. infections in animals and humans. Vet. Parasitol., 2007, 149, 3-21.

Rотн H. The in vitro action of Trichiura larva in immun serum. A new precipitin test in trichinosis. Acta Patbologica Microbiologica Scandinavica, 1941, 18, 160.

van Knapen F., Franchimont J.H., Verdonk A.R., Stumpf J. \& UnDEUTSCH K. Detection of specific immunoglobulins (IgG, $\operatorname{IgM}, \operatorname{IgA}, \operatorname{IgE}$ ) and total IgE levels in human trichinosis by means of the enzyme-linked immunosorbent assay (ELISA). American Journal of Tropical Medicine and Hygiene, 1982, 31, 973-976.

Reçu le 6 mai 2010

Accepté le 17 juin 2010 